\title{
PERSONAL JURISDICTION OVER FOREIGN CORPORATIONS IN DIVERSITY ACTIONS: A TILTYARD FOR THE KNIGHTS OF ERIE
}

Only three years separate the decision of the Court of Appeals for the Second Circuit in Jaftex Corp. v. Randolph Mills, Inc., ${ }^{1}$ and its subsequent overruling in Arrowsmith $v$. United Press Int'l. ${ }^{2}$ The exhaustive opinions in these two cases manifest continuing disagreement about (1) the existence and nature of a federal standard of jurisdiction over foreign corporations and (2) the applicability of a federal standard in a diversity action. ${ }^{3}$

Jaftex involved an attempt to join a North Carolina corporation as a third party defendant in a diversity action brought in the Southern District of New York. The district court dismissed the corporation, holding that although it was subject to suit under federal law it was not subject

1282 F.2d 508 (2d Cir. 1960).

2320 F.2d 219 (2d Cir. 1963) (en banc).

3 The opinions in each case are by Judge Friendly and the late Judge Clark, two scholarly judges long associated with the elements of the controversy-the Federal Rules of Civil Procedure, the "Erie doctrine," and diversity jurisdiction. Remarkably, both Judge Friendly, in January of this year, and Judge Clark, in 1945, chose the application of state law problem, symbolized by Erie, as their topic when invited to give the annual Benjamin N. Cardozo Lecture before the Association of the Bar of the City of New York. For reports of their addresses see Clark, State Law in the Federal Courts: The Brooding Omnipresence of Erie v. Tompkins, 55 YALE L.J. 265 (1946); Friendly, In Praise of Erie-and of the New Federal Common Law, 19 RECORD OF N.Y.C.B.A. 64 (1964) (as refreshing a treatment of the problem as the title indicates).

Judge Clark's association with the Federal Rules began with a provocative article calling for full utilization of the rule-making power Congress had granted the Supreme Court, written at a time when it appeared that the power might be half-heartedly exercised, if at all. Clark \& Moore, $A$ New Federal Civil Procedure, 44 Yale L.J. 387, 1291 (1935). An account of the genesis of the rules can be found in 1 BARRoN \& Holtzoff, Federal Practice and Procedure §§ I-5 (Wright ed. 1960) [hereinafter cited as BARRon \& Holtzoff]. Judge Clark, then Dean of the Yale Law School, served as Reporter to the Advisory Committee on Rules for Civil Procedure that drafted the original Federal Rules and was a member of the Standing Committee on Rules of Practice and Procedure until his death. He spoke and wrote often in support of the rules. Some of his articles particularly relevant to the problem of state law and the rules include: Federal Procedural Reform and States Rights; to a More Perfect Union, 40 Texas L. REv. 211 (1961); Two Decades of the Federal Civil Rules, 58 Colum. L. REv. 435 (1958); The Tompkins Case and the Federal Rules, 1 F.R.D. 417 (1940); Procedural Aspects of the New State Independence, 8 GEO. WASH. L. REV. 1230 (1940); The Handmaid of Justice, 23 WASH. U.L.Q. 297 (1938).

Judge Friendly is the author of The Historic Basis of Diversity Jurisdiction, 41 HARv. L. REV. 483 (1928). 
under New York law, the application of which was required by "the doctrine of Erie Railroad Co. v. Tompkins." Although the court of appeals held that personal jurisdiction existed under either New York or federal law, thus rendering the choice moot, it went on to discuss which law should be applied. The late Judge Clark's majority opinion directed the district court to apply a federal standard. Judge Friendly, in concurring, maintained that state law should be applied.

In Arrowsmith the court seemed to welcome an opportunity to reconsider Jaftex. Arrowsmith, a Maryland resident, had brought a libel action in the Vermont district court against United Press International, a New York corporation. The defendant moved for dismissal for lack of personal jurisdiction, improper venue and failure to state a claim upon which relief could be granted. Without first considering jurisdiction and venue, the district court dismissed the action with prejudice for failure to state a claim. ${ }^{5}$ On appeal, a majority of the panel requested and obtained en banc consideration. Holding that the lower court erred by failing to pass first upon the claims of improper personal jurisdiction and venue, the court of appeals reversed and remanded the case for a consideration of those issues. Most of Judge Friendly's majority opinion is devoted to an advance determination of the standard by which the district court is to decide whether it has jurisdiction over the defendant. He concluded that the "alternative ground of decision in Jaftex, asserting a 'federal standard' for jurisdiction over foreign corporations in ordinary diversity cases, should be overruled." 6 Judge Clark dissented, adhering to the views expressed in his majority opinion in Jaftex.

In both cases Judges Clark and Friendly agreed that if there were a federal statute or rule "expressly or by fair implication"7 providing a standard of personal jurisdiction over foreign corporations or even showing "an intent that the federal courts are 'to fashion federal law ..." on the subject, that authority would govern in diversity as well as federal question cases. Nevertheless, despite this concession to the supremacy of

4 Shawe v. Wendy Wilson, Inc., 171 F. Supp. 117, 119 (S.D.N.Y. 1959). Obviously this is the only situation in which the choice between state and federal standards is significant. If the defendant is subject to suit under both or neither, the choice is merely academic. For purposes of the discussion relating to choice of standards this comment will indulge in the customary assumption that the "federal standard" requires less connection with the state than does the state standard.

5205 F. Supp. 56 (D. Vt. 1962).

6 320 F.2d at 225. Judges Waterman and Smith concurred in the result. Id. at 244.

7 Arrowsmith v. United Press Int'l, 320 F.2d 219, 225 (2d Cir. 1963).

8 Jaftex Corp. v. Randolph Mills, Inc., 282 F.2d 508, 517 (2d Cir. 1960) (concurring opinion). 
congressional provisions for jurisdiction over corporations, Judge Friendly did not believe that such a directive existed. ${ }^{9}$

\section{The Federal Standard of Personal Jurisdiction Over Corporations}

A federal standard has been applied in federal question cases where, in practice, there is little pressure to conform to state law.10 But before the nature of the standard and its possible congressional authorization can be ascertained, a preliminary understanding of terminology must be reached.

A challenge to a court's jurisdiction over a person is fundamentally a query whether the court has the power to enter a valid default judgment against him. ${ }^{11}$ Assuming appropriate subject matter jurisdiction, ${ }^{12}$ two conditions are essential to the validity of a default judgment: (1)

9 "No federal statute or Rule of Civil Procedure speaks to the issue either expressly or by fair implication." Arrowsmith v. United Press Int'l, 320 F.2d 219, 225 (2d Cir. 1963).

10 In theory the application of state law problem is not confined to diversity actions. The Rules of Decision Act, 28 U.S.C. $\$ 1652$ (1958), requires the application of state laws as rules of decision in civil actions in federal courts "except where the Constitution or treaties of the United States or Acts of Congress otherwise require or provide." The opinion in Erie itself states, "Except in matters governed by the Federal Constitution or by Acts of Congress, the law to be applied in any case is the law of the State." 304 U.S. 64, 78 (1938). (Emphasis added.) See Hill, The Erie Doctrine and the Constitution, 53 Nw. U.L. REv. 427, 453 (1958); Snepp, The Law Applied in the Federal Courts, 13 LAw \& Contemp. Prob. 165, 169 (1948); Vestal, Erie R. $R$. v. Tompkins-A Projection, 48 Iowa L. REv. 298 (1963); Note, 62 HARv. L. REv. 1030, 1031 (1949). See generally HaRT \& Wechsler, The Federal Courts and the Federal System 577-708 (1953) [hereinafter cited as HART \& WECHSLER].

It would seem that if there is no congressionally authorized standard of personal jurisdiction over corporations the argument for application of the state standard would be equally applicable, although less hospitably received, in federal question cases as in diversity cases.

11 "Jurisdiction over the defendant ... connotes the requisite power or control to render an in personam ... judgment ...." Moore \& Vestal, MOORE's MANUAL § 7.01, at 382 (1962). In cases, the usual form of the statement is that personal jurisdiction is the power of the court over the parties. E.g., Rensing v. Turner Aviation Corp., 166 F. Supp. 790, 794 (N.D. Ill. 1958). As MOORE \& VESTAL indicates, what is meant is power to enter a valid judgment even if the person fails to appear.

12 Subject matter jurisdiction is the power to hear and adjudicate the kind of controversy. In the federal courts, controversies between citizens of different states are considered to be a kind of controversy which may be adjudicated in district courts. Hence diversity jurisdiction is subject matter jurisdiction. Mississippi Pub. Corp. v. Murphree, 326 U.S. 438, 440-41 (1946).

For purposes of determining whether diversity exists when there is a corporate party, Congress has provided that "a corporation shall be deemed a citizen of any State by which it has been incorporated and of the State where it has its principal place of business." 28 U.S.C. $\$ 1332$ (c) (1958). The question of the citizenship of the corporation for diversity purposes is independent of the question of this comment, which deals with the standard by which it is to be determined whether a corporation is within the personal jurisdiction of the court. 
adequate notice to the defendant; ${ }^{\mathbf{1 3}}$ and (2) the existence, usually at the time of notification, ${ }^{14}$ of a specified relation-e.g., proximity-between the person and the court rendering the judgment.15 Confusion results from the use by the courts of the term "personal jurisdiction" to represent both conditions. But the question whether the person has received adequate notice ${ }^{16}$ is quite independent of the question whether there exists between the person and the court a specified relation ${ }^{17}$ that will support a valid default judgment. ${ }^{18}$ Since the first condition is already adequately identified by the term "notice," clarity will be promoted by reserving the term "personal jurisdiction" to represent only the second condition.

The first question presented is why any particular relation between a court and an intended defendant is required. A fundamental source of this requirement has been the practical limitation of territorial sovereignty; the assertion of one sovereignty's power outside its territorial limits is an invasion of the domain of another sovereignty. ${ }^{19}$ This was

13 "A judgment is void unless a reasonable method of notification is employed and a reasonable opportunity to be heard afforded to persons affected." RESTATEMENT, JUDGMENTs § 6 (1942); Mullane v. Central Hanover Bank \& Trust Co., 339 U.S. 306 (1950). "In addition to some appropriate connection between the defendant and the legal unit in which his case is pending, due process requires that he be given reasonable notice of the proceedings in order that he may make his defense." 2 FreUND, SUTHERLAND, Howe \& Brown, ConstTutional LAW 1081 (1961).

14 See, e.g., Ezell v. Rust Eng'r Co., 75 F. Supp. 980, 982 (W.D.S.C. 1948). But see French v. Gibbs Corp., 189 F.2d 787 (2d Cir. 1951).

15 L. D. Reeder Contractors v. Higgins Indus., Inc., 265 F.2d 768 (9th Cir. 1959); see text accompanying notes 19-21 infra.

16 For the purposes of discussion in this comment it will be assumed that the corporation, through a proper representative, has been given actual notice of the actionan assumption justified by the corporation's invariable resistance of the action in a special appearance-and that the method of notification is constitutionally acceptable. It is possible to upset a judgment in a case in which there has been actual notice by attacking the statutory manner in which notice is to be given as not calculated to give actual notice, Mfullane v. Central Hanover Bank \&: Trust Co., 339 U.S. 306 (1950), but this is a point independent of the question of this comment.

17 Familiar examples of these relations are presence or domicile within the forum area for an individual and doing business within or minimum contacts with the forum area for a corporation. Because of the obvious role of the forum area in stating these relations, they are usually thought of as relations to the area in which the court is located rather than relations to the court itself.

18 Substantially synonymous with this query are questions whether a defendant is subject or amenable to suit or whether it is subject or amenable to service of process.

The questions to be considered in this comment can, on the basis of the analysis in the text above, be accurately but unconventionally restated as (l) what relations have been specified by federal law to be required between a foreign corporation and a district court to support a valid default judgment and (2) whether state or federal law should specify the required relation in a diversity action.

19 Rheinstein, The Constitutional Bases of Jurisdiction, 22 U. GHr. L. REv, 775, 795-96 (1955). 
certainly the historically dominant influence in the development of the restrictions-later read into the fourteenth amendment-on the power of a state over persons outside its boundaries. ${ }^{20}$ Under territorial sovereignty principles-apparently read into the fifth amendment-all that would be required for jurisdiction over a person to exist in a federal court would be that the person be within the territorial limits of the United States. ${ }^{21}$ In the case of a corporation this would automatically be satisfied by incorporation in one of the states. Acceptance of this view means that such a corporation is within the personal jurisdiction of any district court unless the federal system has imposed additional restrictions.

Nevertheless, it might be argued, by analogy to Supreme Court decisions on the constitutional restrictions on state court personal jurisdiction, that an additional constitutional limitation exists. ${ }^{22}$ The Supreme Court has made fairness to the defendant a factor in determining whether he is subject to the personal jurisdiction of state courts. ${ }^{23}$ If such decisions were taken as recognizing a fourteenth amendment due process right not to litigate in an unreasonably inconvenient forum, it might be argued that the defendant in federal courts is afforded a parallel right by the same clause of the fifth amendment. ${ }^{24}$ But no such constitutional right has thus far achieved recognition in the federal system. In situations in which Congress has provided nationwide personal jurisdiction, the "right" does not seem to have even been claimed. ${ }^{25}$ The absence of such claims may be due to the large odds against their succeeding; Congress has not allowed district courts such jurisdiction without good reason to do soi.e., encouraging enforcement of federal laws or facilitating multi-party litigation. ${ }^{26}$ The true test of the constitutionality of a nationwide jurisdiction provision would be presented if such a measure were provided

20 Abraham, Constitutional Limitations Upon the Territorial Reach of Federal Process, 8 VicL. L. REv. 520, 531-32 (1963).

21 Green, Federal Jurisdiction in Personam of Corporations and Due Process, 14 VAND. L. REv. 967, 972, 986 (1961). This is consistent with the frequent dicta of the Supreme Court that there would be no constitutional objection to giving the district courts nationwide service of process. Mississippi Pub. Corp. v. Murphree, 326 U.S. 438, 442 (1946); Robertson v. Raillroad Labor Bd., 268 U.S. 619, 622 (1925); United States v. Union Pac. R.R., 98 U.S. 569, 604 (1878); 'Toland v. Sprague, 37 U.S. (12 Pet.) 300, 328 (1838).

22 Abraham, supra note 20, at 533-35.

23 International Shoe Co. v. Washington, 326 U.S. 310 (1945).

24 Abraham, supra note 20, at 533-35.

25 Although there are a number of federal statutes which provide nationwide service of process, 2 MOORE, FeDeral Practice If 4.42, at 1035-36 (2d ed. 1962) [hereinafter cited as MOORE], there appear to have been no cases raising a due process objection to service outside the state in which the court sits. Abraham, supra note 20, at 535 .

26 Congress has provided nationwide personal jurisdiction-i.e., service of processin order to facilitate enforcement of particular federal laws, e.g., 26 Stat. 210 (1890), 15 U.S.C. § 5 (1958) (Sherman Act); 38 Stat. 731 (1914), 15 U.S.G. \& 15 (1958) (Clayton 
in ordinary diversity litigation without reference to a particular public interest. The question of a constitutionally based claim of unfairness which might be asserted by a Californian being forced under such a provision to litigate in New York is still open, 27 but until such a situation occurs the case law indicates that a reasonable connection with the United States is all that is required to satisfy the constitutional "federal standard." 28

Nonetheless, there are sources other than the Constitution which may require connections between particular district courts and corporations being sued in them; these may be statutes, rules or self-imposed requirements of the federal courts.

Section 1391(c) of the Judicial Code, generally taken to deal only with venue, could be construed to provide a standard of personal jurisdiction over corporations. 29

Act), and in order to serve the public interest in expediting certain kinds of litigation where the states cannot do so, e.g., 28 U.S.C. $\$ 2361$ (Federal Interpleader Act); 28 U.S.C. § 1695 (jurisdiction over corporation in shareholder's action).

FED. R. Crv. P. 4(f) has recently been amended to provide jurisdiction over third parties sought to be joined under rules $13(\mathrm{~h}), 14$ and 19 who can be served within 100 miles of the courthouse, regardless of state boundaries. Despite the public interest in the federal courts performing the distinctly federal function of expediting multi-party litigation, the validity of this measure has not been thought to be so well settled as to foreclose discussion of its validity. See Abraham, supra note 20; Kaplan, Amendments of the Federal Rules of Civil Procedure, 1961-1963 (pt. 1), 77 Flarv. L. Rev. 601, 631-34 (1964); Vestal, Expanding the Jurisdictional Reach of the Federal Courts: The 1963 Changes in Federal Rule 4, 38 N.Y.U.L. REv. 1053, 1059-76 (1963).

27 See Abraham, supra note 20, at 528. This question is unlikely to be litigated since Congress has now provided for transfer of actions "in the interest of justice." 28 U.S.C. $\S \S 1404(a), 1406$ (a) (1958). Arguments based upon inconvenience and unfairness can be founded more firmly upon these statutes. See Comment, 30 U. CHI. L. REv. 735, 743 (1963).

28 The correct interpretation of the language of fairness to the defendant in the state personal jurisdiction cases is probably that fairness is merely a factor taken into consideration in determining the constitutional limits on state power and not an additional constitutional limitation to be reckoned with once it is found the defendant is within the state's power. See Hanson v. Denckla, 357 U.S. 235, 251 (1958) (Restrictions on the personal jurisdiction of state courts "are more than a guarantee of immunity from inconvenient or distant litigation. They are a consequence of territorial limitations on the power of the respective States.') The analogous application of the doctrine of these cases to the federal situation would be that fairness would be a factor in determining whether the United States has power over a defendant.

This is not to say that a constitutional right not to litigate in an unreasonably inconvenient forum may not be emerging. While the shift in emphasis from the territorial boundaries of the state to state interests and the convenience of the defendant has generally resulted in an expansion of the traditional limits on state power, the language could be used in a proper case to make a strong argument in favor of denying the state power to exercise jurisdiction where the inconvenience to the defendant is great and the state's interest is minimal.

29 See, e.g., Paragon Oil Co. v. Panama Ref. \& Petrochem. Co., 192 F. Supp. 259 (S.D.N.Y. 1961). 
A corporation may be sued in any judicial district in which it is incorporated or licensed to do business or is doing business, and such judicial district shall be regarded as the residence of such corporation for venue purposes..$^{30}$

Were it not for labels such as venue and personal jurisdiction, the first half of the subsection would seem to resolve any question as to the standard by which a corporation's amenability to suit is to be determined, with the second part merely silencing objections to venue in those districts in which it may be sued. If this interpretation is a "literalism,"31 then surely a view that the provision has nothing to do with personal jurisdiction because it is in a section of the code entitled "Venue generally" is a "labelism." But restricting the statute's scope to that indicated by its title seems justified by its historical setting. In Neirbo Co. $v$. Bethlehem Shipbuilding Corp., ${ }^{32}$ the Supreme Court, in 1939, held that a corporation had waived any objection it might have had to venue in the district court when it appointed an agent to receive service of process pursuant to a state qualification to do business statute. While of benefit to some plaintiffs, the case produced the anomaly that corporations that did business without complying with the state law were in a better position than those which had complied, since they preserved their objections to venue in the federal courts. It is generally felt that section 1391 (c) was enacted to eliminate this anomaly and that it did not do away with the additional requirement of personal jurisdiction; ${ }^{33}$ indeed, so long as venue may be laid in the plaintiff's district of residence, in a diversity action, the defendant's only protection lies in the personal jurisdiction requirement. It should be apparent, however, that in the federal system there is an intriguing and confusing similarity between personal jurisdiction and venue; both serve to locate the proper place for trial, often by literally the same standard. ${ }^{34}$

3028 U.S.C. § 1391 (c) (1958).

31 Jaftex Corp. v. Randolph Mills, Inc., 282 F.2d 508, 518 (2d Cir. 1960).

32308 U.S. 165 (1939).

33 See Rensing v. Turner Aviation Corp., 166 F. Supp. 790, 795 (N.D. Ill. 1958); Bar's Leaks Western, Inc. v. Pollock, 148 F. Supp. 710, 713-14 (N.D. Cal. 1957); 1 Moore I 0.142 [5.-3]; Note, 69 HaRv. L. REv. 508, 517-19 (1956); Note, 67 Yale L.J. 1094, 1099 n.18 (1958); cf. Polizzi v. Cowles Magazines, Inc., 345 U.S. 663 (1953).

34 It is customarily understood that "doing business" for venue purposes means something different from "doing business" for purposes of personal jurisdiction, although a number of courts have failed to see the distinction. See Judge Friendly's advice to the district court on remand in Arrowsmith and cases there cited. 320 F.2d at 234.

It might be asked what difference it makes whether location of the proper place for a trial is accomplished in one step or two as long as the supposedly more restrictive venue must always be satisfied. See Bar's Leaks Western, Inc. v. Pollock, 148 F. 
An infrequently suggested source of a congressional limitation on district court personal jurisdiction is section 1693 of the Judicial Code. This is the antique, but not entirely anachronistic," "civil arrest" provision, now found in a chapter of the code entitled "Process."

Except as otherwise provided by Act of Congress, no person shall be arrested in one district for trial in another in any civil action in a district court. 36

This provision has descended without significant change from the original Judiciary Act. ${ }^{37}$ To derive a standard of personal jurisdiction over cor-

Supp. 710, 713-14 (N.D. Cal. 1957) ("The question of jurisidiction becomes academic when merged in the larger question of proper venue . . . .). Until 1887 venue and personal jurisdiction in the federal courts were "scarcely distinguishable." HART \& WECHSLER 948. More recently the distinctions which had arisen have been disappearing. Convenience of the parties has become as much a factor in determining personal jurisdiction as it is in determining venue. See Lone Star Package Car. Co. v. Baltimore \& O.R.R., 212 F.2d 147, 154-55 (5th Cir. 1954). Nor does the lack of personal jurisdiction necessarily result in dismissal of the action. In several recent cases transfer has been ordered. Goldlawr, Inc. v. Heiman, 369 U.S. 463 (1962); Hydrotherm, Inc. v. BastianMorley Co., 207 F. Supp. 744 (E.D.N.Y. 1962); Comment, Change of Venue in Absence of Personal Jurisdiction Under 28 U.S.C. 1404(a) and 1406(a), 30 U. CHr. L. Rev. 735 (1963). Both are personal privileges of the defendant which may be waived. 1 MoorE If 0.140 [1.-1].

Apparently only two distinctions remain. In a multi-district state-a defendant will be subject to personal jurisdiction in any district, but venue requires that the trial be held in a district in which it is doing business. And the objection to personal jurisdiction is the only protection against unreasonable inconvenience available to a defendant as of right in a diversity action in which venue may be properly laid in the district of the plaintiff's residence. 28 U.S.C. $\$ 1391$ (a) (1958). (The elimination of the district of plaintiff's residence as a proper place for venue has been proposed recently. ALI, Study of the Drvision of Jurisdiction Between State and Federal Courts \& 1304(a) \&. note (Tent. Draft No. 1, 1963).)

A great deal of confusion surrounds venue and personal jurisdiction (whether as an independent requirement or as a limitation on service of process). Compare, e.g., Rensing v. Turner Aviation Corp., 166 F. Supp. 790 (N.D. Ill. 1958), with Houston Fearless Corp. v. Teter, 318 F.2d 822 (10th Cir. 1963) (Query the legitimacy of using a Supreme Court pronouncement of the constitutional limitation of a state's power over a corporation as a precedent for interpretation of the federal venue statute.). Since both concepts function in the federal system to locate the proper district for trial, it seems that a single comprehensive provision to perform that function would be a great improvement. See Barrett, Venue and Service of Process in the Federal Courts-Suggestions for Reform, 7 VAND. L. REv. 608, 628-29 (1954); Note, Doing Business as a Test of Venue and Jurisdiction Over Foreign Corporations in the Federal Courts, 56 Colun. L. Rev. 394, 420 (1956).

35 In some states commencement of certain civil actions by capias ad respondendum is still provided by statute, e.g., 2A N.J.S.A. § 15-41, 43 (1952). Section 1693 may not be entirely obsolete since a state's capias procedure might be available in the federal court under the provision in rule 4 (d)(7) for service of summons or "other like process" in the manner prescribed by the law of the state in which the district court is held. Fed. R. Civ. P. 4(d)(7).

3628 U.S.C. § 1693 (1958).

37 I Stat. 73,78 (1789). 
porations from it one must first construe it as applicable to the commencement of an action not only by arrest of the defendant pursuant to a writ of capias ad respondendum, but also by service of ordinary process. Although this is a colorable construction-a personal jurisdiction requirement may well take the form of a restriction upon service of process-two factors weigh against it. First, the arrest of the defendant in a civil action is a somewhat drastic measure which might merit special limits on its use. Even more significantly, restrictions upon service of process are now treated in Rule 4 of the Federal Rules of Civil Procedure. ${ }^{38}$

None of the rules purports on its face to deal with personal jurisdiction over corporations, ${ }^{39}$ but when it is recalled that it is an additional restriction upon the district court's constitutional power over a corporation which is sought, it will be seen that rule $4(\mathfrak{f})$, entitled "Territorial Limits of Effective Service," imposes such a restriction. ${ }^{40}$

All process other than a subpoena may be served anywhere within the territorial limits of the state in which the district court is held, and, when authorized by a statute of the United States or by these rules, beyond the territorial limits of that state .... . 11

This subdivision, read together with subdivision (d)(1), ${ }^{42}$ which provides for the manner in which the summons shall be delivered to an individual,

38 The statutory support for a federal standard of personal jurisdiction over corporations is, to say the least, tenuous. Even if $\S 1693$ were construed as applying to all modes of commencing an action, how it treats jurisdiction over corporations would not be apparent. A requirement that a corporation be present within the district by doing business there might be inferred, but it is certainly not implied. The most that can be found in this section is congressional authority upon which a standard of personal jurisdiction, using the district as the significant area, could be constructed, but this is not likely unless the standard seeker is both highly motivated and unaware of the existence of better foundations: e.g., FED. R. Crv. P. 4(f).

39 The subject has never been specifically dealt with by rule or statute. Of the Federal Judiciary Act of 1789, I Stat. 73, (1789) it has been said: "The most important omission on the part of the drafters of the Bill which occurred in connection with the Section relative to the jurisdiction of the Circuit Courts-an omission which had most grave results and which necessitated decisions tantamount to judicial legislation by the Supreme Court-was the neglect to make any provision regarding jurisdiction as to corporations." Warren, New Light on the History of the Federal Judiciary Act of 1789, 37 HARV. L. REV. 49, 89 (1923). This original failure to address the problem can be attributed to the insignificance of the corporate form at that time, Williston, History of the Law of Business Corporations Before 1800, 2 HARv. L. REv. 149, 165-66 (1888) (only 6 corporations chartered in America before 1787), but there is no such excuse now.

40 See Moore \& Vestal, Moore's Manual If 6.02 (1962).

41 Fed. R. Crv. P. 4(f).

42 "Service shall be made as follows: Upon an individual . . . by delivering a copy of the summons and of the complaint to him personally or by leaving copies thereof at his dwelling house or usual place of abode with some person of suitable age and discretion then residing therein ...." FED. R. Grv. P. 4(d)(1). 
makes it reasonably plain that the basic relations required for the existence of power to enter a valid default judgment against an individual are presence or domicile within the state.

As to corporations, subdivision (d)(3) provides that service of process shall be made

Upon a domestic or foreign corporation ... by delivering a copy of the summons and of the complaint to an officer, a managing or general agent, or to any other agent authorized by appointment or by law to receive service of process . . . 43

In First Flight Co. v. National Carloading Corp. ${ }^{44}$ the court took the view that if a corporation has the constitutionally required minimum contacts with the United States the only additional personal jurisdiction requirement is that an agent be handed a copy of the summons and complaint within the state in which the district court is held. This is all the rule expressly requires; however, the facts of the case fail to give unqualified support to this view since the situation presented was the relatively easy one in which the corporation maintained within the state a permanent office with resident agents. The true test of the court's view would be presented if a responsible agent were served with process while traveling - perhaps by air ${ }^{45}$ - through a state with which his corporation had no connection. While a literal interpretation of subdivisions (d)(3) and ( $f$ ) would seem to permit the district court to enter a default judgment should the corporation ignore the notice, no case has been found so holding.

Rather, the clear weight of authority holds that subdivision (d)(3) provides only the manner of notifying a corporation of a suit and does not declare the circumstances under which it is subject to suit. ${ }^{46}$ Although notice must, under subdivision ( $f$ ), be given within the state, something more than mere casual presence of an agent is required. This "something more" is the content of the jurisdiction standard. The usual approach to developing it has been to recognize the notification limitation in rule $4(\mathrm{f})$ and infer that the corporation must be "present" within the state, presence being manifested by "doing business." 47 But the con-

43 FED. R. Crv. P. 4(d)(3).

44209 F. Supp. 730, 739 (E.D. Tenn. 1962).

45 Cf. Grace v. MacArthur, 170 F. Supp. 442 (E.D. Ark. 1959).

46 "Rule 4(d)(3) of the Rules of Civil Procedure tells how service of process is to be made upon a corporation which is subject to service; but it does not tell when the corporation is so subject." HART \& WeCHSLER 959; accord, Smith v. Alexandrian, 80 F.R.D. 553 (N.D. Ill. 1961). See also I Barron \& Holtzoff § 179, at 699.

472 Moore I 4.25. This is, of course, the approach of Judge Clark in Jaftex, 282 F.2d at 512, 516, and in Arrowsmith, 320 F.2d at 238-39. It will be noted, however, 
nection between the rule and the content of the standard is not so clear as to nullify the notion that the required relation is not specified by the rule and may be developed independently.

A review of lower federal court decisions, particularly in federal question cases, indicates that in some of them the restriction on constitutionally permissible personal jurisdiction was wholly judge-made and strongly influenced by Supreme Court decisions ${ }^{48}$ on the constitutional limitations of state court power over corporations. Courts holding this view appear to be aware of the anomaly of construing fourteenth amendment limitations as binding on federal courts, but they still employ the language of those limitations. The best example is found in Lone Star Package Car Corp. v. Baltimore of O.R.R., ${ }^{49}$ a federal question case in which the propriety of requiring the corporate defendant to defend the action in the particular district court was determined by "basic principles of fairness." The court credited the phrase to International Shoe Co. $v$. Washington ${ }^{50}$ and acknowledged that that case dealt with constitutional limitations on state court jurisdiction, but went on to state that "the broad statements of policy expressed ... seem to us to be extended also to cases where the jurisdiction of the federal courts depends upon federal law."51 Other courts have imposed a requirement of "doing business" without attributing it to the compulsion of any higher authority. ${ }^{52}$

The preceding analysis reveals that the three sources-statutes, rules and judge-made law - may be and have been used as a basis for a federal standard of personal jurisdiction over corporations. The inquiry now narrows to the question significant in a diversity case: Whether there is a congressionally authorized standard sufficiently clear that it may be said that Congress has "otherwise required or provided,"53 thus precluding the question of the applicability of state law.

The most likely basis for a congressionally authorized ${ }^{54}$ standard is

that he preferred to use the district as the significant area, apparently out of an inclination to rely on 28 U.S.C. $\S 1693$.

48 E.g., International Shoe Co. v. Washington, 326 U.S. 310 (1945).

49212 F.2d 147 (5th Cir. 1954). The Lone Star approach was employed in Goldberg v. Mutual Readers League, Inc., 195 F. Supp. 778 (E.D. Pa. 196I), also a federal question case.

50326 U.S. 310 (1945).

51212 F.2d at 155. (Emphasis added.)

52 See, e.g., Pike v. New Eng. Greyhound Lines, Inc., 93 F. Supp. 669 (D. Mass. 1950).

53 See text accompanying notes 73-75 infra.

54 The rules have at least passive congressional authorization. They are promulgated by the Supreme Court pursuant to a grant of authority from Congress. 28 U.S.C. $\S$ 2072 (1958). Once promulgated, rules and amendments are transmitted to Congress and take effect after a stated period of time if Congress takes no adverse action. Ibid. Faced 
rule $4(f) .{ }^{55}$ By far the most common form of any personal jurisdiction standard is that of a condition to effective service of process or to amenability to service. ${ }^{56}$ That the state is the significant area in the standard points to rule $4(f)$ as its source, since prior to the rule's adoption the district clearly was regarded as the significant area. ${ }^{.7}$

If rule $4(f)$ explicitly provided the manner in which it applied to corporations, it, rather than state law, would clearly govern. ${ }^{58}$ In Iovino $v$. Waterson $^{50}$ the Court of Appeals for the Second Circuit dealt with an analogous situation, substitution of a non-resident administratrix for a deceased party in a diversity action. The question was essentially one of personal jurisdiction over the administratrix, who could not be served within New York, the location of the action. Personal jurisdiction did not exist under New York law, but did exist under federal rule 25(a)(l) which clearly provides that service upon a party to be substituted for a deceased party may be made in any judicial district. In an opinion written by Judge Friendly the court applied rule 25(a)(I) and upheld jurisdiction.

Rule $4(f)$ is not as lucid regarding the relations required to give a court power over a corporation as is rule $25(\mathrm{a})(\mathrm{l})$ regarding substitution, but if its application requires only interpretation, an argument that it would accordingly prevail over state law could be based on the recent Supreme Court decision in National Equipment Rental, Ltd. v. Szukhent. ${ }^{60}$ The main issue in this diversity action was whether the defendants, Michigan farmers, had consented to be sued in New York by appointing a local agent to receive process. The supposed appointment

with the question of the rules' status in Sibbach v. Wilson \& Co., 312 U.S. 1 (1940), the Supreme Court, split five to four, stated that a rule "has the force of a federal statute." Accord, American Fed. Musicians v. Stein, 213 F.2d 679 (6th Cir.), cert. denied, 348 U.S. 873 (1954); Note, 62 Harv. L. Rev. 1030, 1031 (1949).

65 See Moore \& Vestal, Moore's Manual ff 6.02 (1962).

56 See, e.g., Bar's Leaks Western, Inc. v. Pollock, 148 F. Supp. 710, 712 (N.D. Cal. 1957) (question put as whether "amenability to process" is to be determined by state or federal standards).

57 Clark \& Moore, A New Federal Civil Procedure, 44 YALE L.J. 387, 410 n.109 (1935).

58 This is so whether Erie is considered to be a constitutional doctrine or not, because of the non-substantive nature of personal jurisdiction. Arrowsmith v. United Press Int'l, 320 F.2d at 226: "Despite contrary intimations as to our position in the dissent, we fully concede that the constitutional doctrine announced in Erie R.R. v. Tompkins . . would not prevent Congress or its rule-making delegate from authorizing a district court to assume jurisdiction over a foreign corporation in an ordinary diversity case although the state court would not ..." Judge Friendly has since characterized his reliance on Erie in Jaftex as "an aberration later righted, 320 F.2d at 226." Friendly, In Praise of Erie-and of the New Federal Common Law, 19 RECORD OF N.Y.C.B.A. 64, $95 \mathrm{n} .23$ (1964). But see Abraham, supra note 20, at 530.

59274 F.2d 41 (2d Cir. 1959) (Friendly, J.).

60375 U.S. 311 (1964). 
of the agent, ${ }^{61}$ whom the defendants had never seen, was in a rather insignificant paragraph of the lessor's lease form, signed by the defendants in Michigan. Mr. Justice Black unsuccessfully argued that the New York law of agency, under which he felt the agency would be invalid, should be applied. The Court, however, construing rule 4(d)(1)'s provision for service of an agent authorized by appointment to receive service or process, held that under "this uniform Federal standard" a valid agency had been created by the appointment in the lease form together with the subsequent actions of the agent. ${ }^{62}$ The holding implicitly recognized that rule 4 sets up jurisdictional standards independent of state law.

Further support for the argument that a standard of jurisdiction over corporations may be based on rule $4(f)$ could be drawn from Monarch Ins. Co. v. Spach. ${ }^{63}$ In this diversity case rule $43(\mathrm{a})^{64}$ did not clearly authorize the admission of a statement given by the president of the insured to the insurer, but it was admitted under an interpretation of the rule despite the contention that it would be excluded under state law.

But the argument that the federal standard is simply an interpretation of rule $4(f)$ and shares the rule's status seems neither to have been made nor to have prevailed in any court of appeals case except Jaftex. ${ }^{65}$

61 It appears from the opinions that the "agent" of the Michigan farmers was in reality the wife of one of the officers of the lessor. 375 U.S. at 317.

62375 U.S. at 316. A distinguishing point, and one responsible for much of the confusion about personal jurisdiction over corporations, is that while in Szukhent the Court was construing an express provision of rule $4(\mathrm{~d})(1)$, the application of rule $4(\mathrm{f})$ to corporations involves the construction of an implied requirement of a relationship to the area of the state. Perhaps the true analogy to Szukhent would be presented if rule $4(f)$ provided that a corporation to be served must be "doing business" within the state and the contention were made that state decisions on the meaning of "doing business" must be followed.

63281 F.2d 401 (5th Cir. 1960).

64 FED. R. Crv. P. 43(a).

65 Cases applying state law in a diversity action when clearly faced with the choice between state and federal standards include, by circuits: First, Pulson v. American Rolling Mill Co., 170 F.2d 193 (1st Cir. 1948); Third, Partin v. Michaels Art Bronze Co., 202 F.2d 541 (3d Cir. 1953); Seventh, Roberts v. Evans Case Co., 218 F.2d 893 (7th Cir. 1955); Canvas Fabricators, Inc. v. W. E. Hooper \& Sons Co., 199 F.2d 485 (7th Cir. 1952); Eighth, Jennings v. McCall Corp., 320 F.2d 64 (8th Cir. 1963); Hilmes v. Marlin Firearms Co., 136 F. Supp. 307 (D. Minn. 1955); Ninth, Kenny v. Alaska Airlines, Inc., 132 F. Supp. 838 (S.D. Cal. 1955). A number of cases have followed state law when service was attempted under it via rule $4(d)(7)$ in circumstances which imply that the courts felt that state law on jurisdiction over corporations must be applied in a diversity case (by circuits): First, Waltham Precision Instrument Co. v. McDonnell Aircraft Corp., 310 F.2d 20 (lst Cir. 1962); Fourth, Shealy v. Challenger Mfg. Co., 304 F.2d 102 (4th Cir. 1962); Iliff v. American Fire Apparatus Co., 277 F.2d 360 (4th Cir. 1960); Easterling v. Cooper Motors, Inc., 26 F.R.D. 1 (M.D.N.C. 1960); Fifth, Stanga v. McCormick Shipping Corp., 268 F.2d 544 (5th Gir. 1959); Sixth, Shuler v. Wood, 198 F. Supp. 801 (E.D. Tenn. 1961); Eighth, Charles Keeshin, Inc. v. Gordon Johnson Co., 109 F. Supp. 939 (W.D. Ark. 1952); Tenth, Walker v. General Features Corp., 319 
Although doing so less articulately, most courts reach the result of Arrowsmith.60 Even though advocates of a state standard of jurisdiction over corporations may recognize the relevance of rule $4(f)$ and concede the supremacy of a clear federal rule or even of an interpretation of a federal rule, they maintain that rule $4(f)$ is not clear and that a congressionally authorized standard of jurisdiction cannot be developed by mere interpretation of the rule. ${ }^{67}$ Rather, there is a gap, an interstice, in the rule, ${ }^{68}$ and the standard filling in that omission does more than merely interpret and must stand or yield to state law wholly on its own.69

The advocates of a federal standard are willing to defend their position on this ground as well; they argue that even if the federal standard cannot be satisfactorily tied to congressional authority the federal courts are free to develop their own standards in diversity as well as federal question cases. 70

\section{Application of a Federal Standard in Diversity Cáses}

The problem of applying state standards of personal jurisdiction over corporations would have been with us even without the Erie decision, since these standards are almost always statutory.71 Yet apparently the leading case requiring their application in diversity actions was decided as recently as 1948,72 ten years after Erie. This raises two questions: How was the question of a standard of jurisdiction over corporations treated before Erie? How and why has Erie changed this?

F.2d 583 (10th Cir. 1963); Steinway v. Majestic Amusement Co., 179 F.2d 681 (10th Cir. 1949).

The only case which has been found that faced the choice of law and chose the federal standard in a diversity case outside the Second Circuit is Pike v. New Eng. Greyhound Lines, Inc., 93 F. Supp. 669 (D. Mass. 1950). Of the cases citing Jaftex, none outside the Second Circuit appears to have followed it.

66 Cases cited note 65 supra.

67 "No federal statute or Rule of Civil Procedure speaks to the issue either expressly or by fair implication." 320 F.2d at 225. (Emphasis added.)

68 The majority in Arrowsmith expressed the belief "that neither the federal legislature nor the federal rule-makers have had any intention to displace state statutes ...." which it felt were otherwise applicable. 320 F.2d at 227. (Emphasis added.)

There are cases in which the courts indicated that they felt state law would have to be applied in a diversity case even if there were a clear federal rule on the subject, but, needless to say, the courts were not faced with that question and gave it little consideration. This makes for weak dicta. See, e.g., Canvas Fabricators, Inc. v. W. E. Hooper \& Sons Co., 199 F.2d 485 (7th Cir. 1952).

69 See Vestal, Erie R.R. v. Tompkins: A Projection, 48 IowA L. REv. 248, 250 (1963).

70 See Arrowsmith v. United Press Int'l, 320 F.2d at 234, 240 (Clark, J., dissenting); Pike v. New Eng. Greyhound Lines, Inc., 93 F. Supp. 669, 671 (D. Mass. 1950).

71 Friendly, In Praise of Erie-and of the New Federal Common Law, 19 RECORD OF N.Y.C.B.A. 64, 78 (1964).

72 Pulson v. American Rolling Mill Co., 170 F.2d 193 (Ist Cir. 1948). 
Section 34 of the Federal Judiciary Act of 1789, the Rules of Decision Act, provided:

That the laws of the several states, except where the constitution, treaties or statutes of the United States shall otherwise require or provide, shall be regarded as rules of decision in trials at common law in the courts of the United States in cases in which they apply. ${ }^{73}$

The provision is continued in much the same form in the present Judicial Code. ${ }^{74}$ Thus it would seem that if a federal court can find no rule to resolve the controversy in the federal constitution or statutes, it is required to turn to the law of the state if a state law applicable to the case exists. ${ }^{75}$

But early in the history of the federal judiciary it became apparent that section 34 did not pertain to all subjects of law, but only to those characterized as "substantive."76 One indication of this was the passage, immediately subsequent to passage of section 34, of the first Process Act, ${ }^{77}$ adopting state court procedure for federal courts. The need to provide separately for the adoption of state practices in the area of "procedure" indicates that such laws were not thought to have been already adopted by section $34 . .^{78}$

But the personal jurisdiction standards of the district courts were found to be governed by neither the Rules of Decision Act nor the Process Act. ${ }^{79}$ And although there were two provisions in section 11 of the Judiciary Act-one on civil arrest and the other on bringing suit ${ }^{80}$ conceded by the courts to be relevant to personal jurisdiction, the dominant view was that restrictions on the personal jurisdiction of the

73 l Stat. 92 (1789).

7428 U.S.C. § 1652 (1958).

75 See Vestal, supra note 69 , at 250-51.

76 See Dobie, Fedral Jurisdiction and Procedure 559 (1928).

77 "[T] $]$ he forms of writs and executions, except their style, and modes of process ... in the circuit and district courts, in suits at common law, shall be the same in each state respectively as are now used or allowed in the supreme courts of the same." 1 Stat. 93 (1789). "Modes of process" was construed to mean "modes of proceeding" in Picquet v. Swan, 19 Fed. Cas. 609, 610 (No. 11,134) (C.C.D. Mass. 1828).

78 See Blume \& George, Limitations and the Federal Courts, 49 Mich. L. REv. 937, 938 (1951).

79 See Picquet v. Swan, 19 Fed. Cas. 609, 610 (No. 11,134) (C.C.D. Mass. 1828); Ex parte Graham, 10 Fed. Cas. 911 (No. 5657) (C.C.E.D. Pa. 1818).

80 "But no person shall be arrested in one district for trial in another, in any civil action before a circuit or district court. And no civil suit shall be brought before either of said courts against an inhabitant of the United States, by any original process, in any other district than that whereof he is an inhabitant, or in which he shall be found at the time of serving the writ ... ." 1 Stat. 79 (1789). 
courts arose from the organization of the courts itself. In Picquet $v$. $S w a n,{ }^{81}$ it was argued that personal jurisdiction of a United States citizen domiciled abroad could be established under a state attachment statute which, it was contended, was made applicable by the Process Act. In rejecting this argument, Mr. Justice Story discussed personal jurisdiction in light of the section 11 provisions and concluded:

That by the general provisions of the laws of the United States, the Circuit Courts could issue no process beyond the limits of their districts. That independent of positive legislation, the process can only be served upon persons within the same districts .... ${ }^{82}$

Mr. Justice Story's reasoning on this point was endorsed by the Supreme Court in Toland $v$. Sprague.83 The prevalence of this view is further indicated by Ex parte Graham, 84 in which Mr. Justice Washington, noting that special provisions had been made by Congress for the extraterritorial service of subpoenas and executions even though they were not within the restriction imposed by section 11, stated:

It would seem, that these provisions were made, not because they were supposed by congress to be necessary, in consequence of the 1Ith section of the judiciary law; but because the jurisdiction of the courts, was essentially confined, by their organization, within the limits of their respective districts . . . ${ }^{85}$

Hence it seems that, in the absence of federal legislation, standards of personal jurisdiction were to be deduced by the federal courts from the character of the federal judiciary, without regard to state personal jurisdiction statutes.

Questions of personal jurisdiction over corporations were so treated. ${ }^{86}$ Section 11 said nothing of the requirements of jurisdiction over corporations. ${ }^{87}$ Until the second half of the nineteenth century the federal courts inferred from the discussion of the existence of a corporation in Bank of Augusta $v$. Earle 88 that a corporation could not be sued except in the state of its incorporation. ${ }^{89}$ The proliferation of multi-state corporations

8119 Fed. Cas. 609 (No. 11,134) (C.C.D. Mass. 1828).

82 Id. at 615. (Emphasis added.)

8337 U.S. (12 Pet.) 300, 328 (1838).

8410 Fed. Cas. 911 (No. 5657) (C.C.E.D. Pa. 1818).

85 Id. at 912.

86 See Henderson, The Position of Foreign Corporatrons in American ConstituTIONAL LAW 87 (1918).

87 Quoted supra note 80.

8838 U.S. (13 Pet.) 517 (1839).

89 Pomeroy v. New York \& N.H.R.R., 19 Fed. Cas. 965 (No. 11,261) (C.C.S.D.N.Y. 
made these holdings highly impractical, however, and they were overruled in Ex parte Schollenberger.$^{90}$ Suit was there allowed against a foreign corporation which had been required to consent to be sued in the courts of the state as a condition of being allowed to do business in the state. The Supreme Court construed the consent exacted by the state to be consent to suit in the federal courts as well, but made it clear that the state statute was not being adopted; the statute and the consent of the corporation had merely brought about a state of facts which enabled the federal court to take the case. ${ }^{91}$ Clearly it was not any assumed compulsion of the Rules of Decision Act which made the state statute relevant in the federal court.

Not long after the turn of the century the consent theory gave way to one of presence; the corporation was deemed to be present if doing business within the district.92 The personal jurisdiction of the district court was no longer dependent upon a state statute exacting consent. ${ }^{93}$ Indeed state statutes would seem to have lost all relevance to district court personal jurisdiction by this time. Conformity to current state court procedure was required by the Conformity Act, ${ }^{94}$ which had been passed five years before the Schollenberger decision, but it was expressly held that even under the state service of process statutes thus adopted the territorial limit on service was the district, not the state. ${ }^{95}$ Thus state personal jurisdiction standards were not adopted by either the Rules of Decision Act or the Conformity. Act and only partial reliance was placed upon the potentially controlling statutory provisions of section 11 and its successors. Personal jurisdiction was neither substantive nor procedural but incidental to the organization of the federal judiciary, from which the courts deduced their own standards of personal jurisdiction over corporations.

In 1938 both the Federal Rules of Givil Procedure and the decision in Erie R.R. v. Tompkins ${ }^{96}$ came into being, with the result that the

1857); Day v. Newark India-Rubber Mfg. Co., 7 Fed. Cas. 245 (No. 3865) (C.C.S.D.N.Y. 1850).

9096 U.S. 369 (1877).

$91 \mathrm{Id}$. at 377.

92 Note, 35 Colum. L. REv. 591, 593 (1935).

93 Ibid.

9417 Stat. 196 (1872).

95 Sewchulis v. Lehigh Valley Coal Co., 233 Fed. 422 (2d Cir. 1916); Dobie, op. cit. supra note 76, at 593; Clark \& Moore, $A$ New Federal Civil Procedure, 44 YALE L.J. 387,410 n.109 (1935) (" $[T]$ he process of a district court will not run into another district, even within the same state, although process of the state nisi prius court would run throughout the state."); cf. Robertson v. Railroad Labor Bd., 268 U.S. 619 (1925).

96304 U.S. 64 (1938). 
foundation of the federal standard was weakened at the same time the argument for the application of state standards was strengthened. The new rules disturbed the existing federal standard of personal jurisdiction over corporations in two ways. Rule $4(f)$ violated the sanctity of the district boundaries by enlarging the area in which effective service of process could be made from the district to the state in multi-district states. ${ }^{97}$ Although this development was resisted, it was finally upheld in the Supreme Court. ${ }^{88}$ Thus the federal jurisdiction standards were detached from the organization of the judiciary and based in a rule.

In addition, subdivision (d)(7) of rule 4 authorized service in the manner prescribed by the law of the state as an alternative to service under other subdivisions of the rule. ${ }^{99}$ Because state statutes often included substituted and extra-territorial service provisions-advantages not otherwise provided in rule $4^{100}$ - the federal courts were urged by plaintiffs to employ them, despite subdivision ( $f$ )'s restriction of effective service to the state. ${ }^{101}$ When a court acceded to this request, as most now

97 As originally adopted rule $4(f)$ read: "Territorial Limits of Effective Service. All process other than a subpoena may be served anywhere within the territorial limits of the state in which the district court is held and, when a statute of the United States so provides, beyond the territorial limits of that state. A subpoena may be served within the territorial limits provided in Rule 45." FED. R. Crv. P. 4(f). See also Devier v. George Cole Motor Co., 27 F. Supp. 978 (W.D. Va. 1939); 1 EdMunds, Federal Rules of CiviL. Procedure 172-73 (1938).

98 A few courts, citing rule 82 , "These rules shall not be construed to extend or limit the jurisdiction of the United States district courts or the venue of actions therein," resisted the expansion of personal jurisdiction and continued to require service of process within the district. Carby v. Greco, 31 F. Supp. 251 (W.D. Ky. 1940); Melekov v. Collins, 30 F. Supp. 159 (S.D. Cal. 1939). But the Supreme Court upheld the expansion in Mississippi Pub. Corp. v. Murphree, 326 U.S. 438 (1945), by construing the rule 82 prohibition against a rule's affecting "jurisdiction" to refer only to subject matter jurisdiction.

98 "Upon a defendant of any class referred to in paragraph (1) or (3) or this subdivision of this rule, it is also sufficient if the summons and complaint are served ... in the manner prescribed by the law of the state in which the service is made for the service of summons or other like process upon any such defendant in any action brought in the courts of general jurisdiction of that state." FED. R. Crv. P. 4(d)(7) (as originally adopted).

100 It is ironic that the current supporters of the application of state standards regard them as more restrictive than a federal standard. Even the recent amendments to the rules left the adopted state extraterritorial service provisions as the only such provisions generally available in the district courts. It is conceivable that a situation might arise in which a court determined that a corporation was within the federal standard of jurisdiction and yet the corporation had no agent within the state to whom notice could be given. In order to notify the corporation the court would have to use the state provision for extraterritorial notification, unless it was willing to abandon compliance with the rules. The only exceptions to rule 4(f)'s limitation of service to the state are federal statutes, which are not generally applicable, and other rules so providing. In their amended form only rule 4(e) provides general extraterritorial service of summons and that only by adoption of state law.

101 Some courts construed rule 4 (d)(7) as adopting only the mechanics of giving notice, 
have and indeed must under the new amendments to rules $4(\mathrm{e})$ and $4(f), 102$ it found itself, in addition to applying the state notification formalities which it had used under the Conformity Act, applying for the first time the jurisdictional standards that were an integral part of the extraterritorial service statutes. ${ }^{103}$ Thus the new rules had the effect of loosening not only the boundaries of the district, but also those of the state. And the courts became accustomed to using the state jurisdiction of corporations standards.

A few months before the Federal Rules took effect the Court handed down its decision in Erie. The decision overruled Swift $v$. Tyson ${ }^{104}$ which had held that the word "laws" in the Rules of Decision Act did not include state decisional law of a general nature, but only statutory and

limited by subdivision ( $f$ ) to being carried out within the state. McCoy v. Siler, 205 F.2d 498, 501 (3d Cir. 1953) (concurring opinion); Smith v. Alexandrian, 30 F.R.D. 553, 555-56 (N.D. Ill. 1961). More recently the weight of authority has maintained that state extraterritorial service provisions could be adopted under subdivision (d)(7) and were not limited by subdivision (f). Giffin v. Ensign, 234 F.2d 307, 310-11 (3d Cir. 1956); Berk v. Bailey, 31 F.R.D. 201, 205 (W.D.S.C. 1962); Kappus v. Western Hills Oil, Inc., 24 F.R.D. 123, 127 (E.D. Wis. 1959). See also 1 BARRon \& Holtzoff \& 184; Comment, 27 U. ChI. L. Rev. 751 (1960).

This result was termed "salutary" by the Advisory Committee in its notes to the recent amendments. Advisory Commitree on Civil Rules, Note to Rule 4(d)(7), H.R. Doc. No. 67, 88th Cong., 1st Sess. (1963). The changes made in those amendments no longer require that interpretation to reach the result, however. Authorization for the use of state extraterritorial service statutes was specifically made in subdivision (e) which was amended to read: "Service Upon Party Not Inhabitant of or Found within State. ... Whenever a statute or rule of court of the state in which the district court is held provides ( 1 ) for service of a summons . . . upon a party not an inhabitant of or found within the state . . . service may . . . be made under the circumstances and in the manner prescribed in the statute or rule." Hence subdivision (d)(7) adopts only the manner of service within the state. 2 MOORE I 4.32 [approved in ADvisory Commitree on Civil Rules, Note to Rule 4(e), H.R. Doc. No. 67, 88th Cong., Ist Sess. (1963)]. But see Vestal, Expanding the Jurisdictional Reach of the Federal Courts: The 1963 Changes in Federal Rule 4, 38 N.Y.U.L. REv. 1053, 1056 (1963).

Subdivision (f) was amended to allow extraterritorial service pursuant to subdivision (e): "All process ... may be served ... when authorized . . . by these rules, beyond the territorial limits of that state." FED. R. Crv. P. 4(f).

102 See note 101 supra.

103 E.g., Wis. STat. ANN. tit. 25, § 262.09(4) (1957): "If the defendant is a foreign corporation .... and (a) is doing business in Wisconsin at the time of service, or (b) the cause of action against it arose out of the doing of business in Wisconsin, service may be made ... by delivering within or without the state a copy of the summons to any officer, director or managing agent of the corporation." Any notion that only the state manner of giving notice is adopted and that the accompanying specification of required relations to the state is not, is clearly refuted by the amended provision in subdivision (e) that "service may ... be made under the circumstances and in the manner prescribed in the [state] statute or rule." FED. R. Crv. P. 4(e). Certainly the circumstances contemplated can be none other than the personal jurisdiction relations that are built into the state service of process statute.

10441 U.S. (16 Pet.) I (1842). 
purely local decisional law. Mr. Justice Brandeis's opinion, however, contained references to the Constitution ${ }^{105}$ that have sparked a long and lively debate whether the decision was constitutionally required, i.e., whether and to what extent Congress can provide the law to be applied in diversity actions. ${ }^{100}$ This controversy does not bear directly on the choice of standards of jurisdiction over corporations, since it is generally agreed that even if the result in Erie were constitutionally required Congress could provide standards of personal jurisdiction to be applied in diversity cases. ${ }^{107}$

But Erie has had a significant indirect effect on the choice of standards of jurisdiction to be applied in a diversity action. The language of the opinion invited reexamination of the reasons for the application of state law. Of the course of the reexamination conducted in subsequent cases, it has been observed:

One point is clear: application of the Erie principle has spread beyond the Erie decision itself. Erie was a construction of the Rules of Decision Act, holding that the decision law of a state was as much "state law" as was statutory law; in contrast all three of the most recent Erie decisions [Cohen, Ragan bo Woods] $]^{108}$ involved the problem whether a state statute was within Erie. It is apparent that what Mr. Justice Rutledge called the "gloss" of Erie has extended the doctrine beyond the narrow decision of the Erie case; this gloss has developed around the

105 "If only a question of statutory construction were involved, we should not be prepared to abandon a doctrine so widely applied throughout nearly a century. But the unconstitutionality of the course pursued has now been made clear and compels us to do so ...." 304 U.S. at 77-78.

"There is no federal general common law." Id. at 78. "We merely declare that in applying the doctrine this Court and the lower courts have invaded rights which in our opinion are reserved by the Constitution to the several states." Id. at 80 . Judge Clark characterized these as somewhat unnecessary "sledge-hammer blows." Clark, State Law in the Federal Courts: The Brooding Omnipresence of Erie v. Tompkins, 55 YALE L.J. 267, 295 (1946).

100 See Abraham, Constitutional Limitations Upon the Territorial Reach of Federal Process, 8 VIIL. L. REv. 520, 523-31 (1963); Friendly, In Praise of Erie-and of the New Federal Common Law, 19 ReCoRD of N.Y.C.B.A. 64 (1964); Hill, The Erie Doctrine and the Constitution, 53 Nw. U.L. Rxv. 427, 541 (1958); Kurland, Mr. Justice Frankfurter, the Supreme Court and the Erie Doctrine in Diversity Cases, 67 YALE L.J. 187, 188-204 (1957); Vestal, Erie R.R. v. Tompkins-A Projection, 48 IowA L. REv. 248, 252-56 (1963); Comment, The Constitutional Power of Congress to Control Procedure in the Federal Courts, 56 Nw. U.L. REv. 560 (1961).

107 See Note, 56 Colum. L. REv. 394, 400 (1956); authorities cited note 106 supra, except Abraham.

108 Cohen v. Beneficial Indus. Loan Corp., 337 U.S. 541 (1949); Woods v. Interstate Realty Co., 337 U.S. 535 (1949); Ragan v. Merchants Transfer \& Warehouse Co., 337 U.S. 530 (1949). 
principle of uniformity of result in a given case, whether suit is brought in state or federal court . . . 100

This expansion has in part been brought about by repeated attempts to reformulate the test to determine whether state or federal law ought to be applied. The substantive-procedural test associated with the Rules of Decision Act-which had not required the application of state statutes providing for jurisdiction over corporations-enjoyed a term of popularity, 110 but its shortcomings were laid bare by Mr. Justice Frankfurter in Guaranty Trust Co. v. York. ${ }^{111}$ Declaring that in diversity cases the federal court was "in effect, only another court of the State,"112 Justice Frankfurter proposed that the test be whether disregarding the particular state law would significantly affect the result of a litigation, often referred to as the "outcome-determinative" test. 113 Once these views had been announced there was no hope that the subject of personal jurisdiction over corporations would remain untouched by the application of state law controversy. ${ }^{114}$ This, together with the previously indicated developments that had unsettled the pre-1938 conception of district court personal jurisdiction, ${ }^{115}$ made inevitable a decision like that in Pulson $v$. American Rolling Mill Co., ${ }^{116}$ which almost assumed state law had to be applied.117

109 Horowitz, Erie R.R. v. Tompkins-A Test to Determine Those Rules of State Law to Which Its Doctrine Applies, 23 So. CALIF. L. Rev. 204, $212-13$ (1950).

110 See Tunks, Gategorization and Federalism: "Substance" and "Procedure" After Erie Railtoad v. Tompkins, 34 ILL. L. REv. 271 (1939).

111326 U.S. 99 (1945).

$112 I d$. at 108.

$113 \mathrm{Id}$. at 109 .

114 The outcome-determinative test has been criticized on the basis that even the most procedural rules may significantly affect the outcome of a litigation. HART \& WECHSLER 678. In some respects a personal jurisdiction standard might be considered the archetype of such a rule. See text accompanying note 130 infra.

115 Traditional views of jurisdiction of corporations were themselves unsettled in the same year as the York case. International Shoe Corp. v. Washington, 326 U.S. 310 (1945).

116170 F.2d 193 (1st Cir. 1948). The Seventh Gircuit's decision that state law on jurisdiction over corporations must be applied was even more casual. See Canvas Fabricators, Inc. v. W.E. Hooper \& Sons Co., 199 F.2d 485, 486 (7th Cir. 1952).

117 There has been a continuing proliferation of tests since York. Each seems to add more confusion since in addition to increasing the number of tests to consider, the application of the particular test to a particular rule is usually unclear. Some of the tests follow: Whether application of a different rule in the federal court promotes forum shopping, Horowitz, supra note 109, at 215; whether a rule affects conduct at the stage of primary private activity, HART \& WECHSLER 678; whether a rule in advance of trial, taken in the abstract, is such as to substantially favor one side or the other in litigation, Kurland, Book Review, 67 HaRv. L. REv. 906 (1954). Cf. Cohen v. Beneficial Indus. Loan Corp., 337 U.S. 541, 555 (1949) ("[I]n diversity cases the federal court administers the state system of law in all except details related to its own conduct of business.') 
The subsequent acceptance of the Pulson decision makes it clear that the time is past for successfully arguing that personal jurisdiction over corporations is a subject exempt from the application of state law controversy. ${ }^{118}$ The issue of the proper standard of jurisdiction over corporations to apply in the absence of clear congressional direction must be determined in the present Erie framework.

A change in approach to state-federal choice of law questions is the most striking feature of post-Erie doctrine. The apparently boundless broadening of scope has spawned an effective presumption that any possibly relevant state law ought to be applied whenever a state-created right is being adjudicated. ${ }^{119}$ It is fashionable, it will be seen, ${ }^{120}$ to weigh the relevant state and federal interests, but there is a burden of persuasion placed upon the advocate of federal law; he must justify "displacing" the state law. ${ }^{121}$ In what were traditionally non-substantive areas not included by the choice of law controversy-e.g., personal jurisdiction of corporations-this shift of burden is most keenly felt and may be decisive. ${ }^{122}$ The burden has, however, been met in a few significant cases.

The foremost of these is Byrd v. Blue Ridge Rural Elec. Co-op, Inc., ${ }^{123}$ in which the defendant's immunity to the plaintiff's common-law personal injury action depended on whether it was a "statutory employer" under the state workmen's compensation act. The state supreme court had held that this issue was to be determined by the judge, not a jury. The defendant contended that the holding must be followed "to secure uniform enforcement of the immunity created by the state." 124

The court first put the issue in perspective by stating that the method

118 See I BARRoN \& HoltzofF § 179, at 696; cases cited note 65 supra.

118 The most striking example of this in the area of jurisdiction of corporations is found in Canvas Fabricators, Inc. v. W.E. Hooper \& Sons Co., 199 F.2d 485 (7th Cir. 1952).

120 See text accompanying notes $128-29$ infra.

121 See Vestal, supra note 106, at 259-72. "Displace" is the term used by Judge Friendly in Arrowsmith. 320 F.2d at 227. This approach is clearly indicated by the characterization of the federal interests as "countervailing considerations." See text accompanying note 128 infra. Contrast the following statement of Judge Clark: "I believe there is good ground for the view that the federal courts are not required to and, in view of the federal rules, should not, hold that an issue traditionally procedural or on the border line is substantive unless the public policy of the state, as unequivocally disclosed by some clear state statute or decision, demands such a result." Clark, The Tompkins Case and the Federal Rules, 1 F.R.D. 417, 419 (1941).

122 Assuming a hypothetical, purely neutral federal rule, the mere inclusion of the subject of the rule within the Erie controversy together with the imposition of a burden of persuasion that the state law should not be applied-which would, by hypothesis, be impossible to meet-would require that the state law be applied.

123356 U.S. 525 (1958).

124 Id. at 534. 
of determining a fact neither constituted, nor was so bound up with, a state-created right and obligation that federal courts must unquestionably apply the state rule. ${ }^{125}$ The same may be said of a rule of jurisdiction over corporations.

The Court did, however, recognize the "broader policy" of conformity in the post-Erie cases and went on to consider the issue in the context that even a non-substantive state rule might have to be applied in the absence of federal legislation if disregarding it would significantly affect the result of the case. ${ }^{128}$ In the course of this consideration the court dispelled any illusions that the outcome-determinative category was allinclusive or all-powerful. That there are limits to the scope of the category is shown by the Court's holding that there was not even a "strong possibility" that the result of the case would be different if the statutory employer issue were determined by a jury rather than by a judge. ${ }^{127}$ Moreover, it was held that even if the choice were labelled outcome-determinative that did not irrevocably decree that the state law must be applied; indeed, the state decision giving the statutory employer issue to the judge was not followed because of the "affirmative countervailing consideration" that distribution of trial functions between judge and jury-including a "federal policy" in favor of jury determinations of disputed questions of fact ${ }^{128}$ - was an essential characteristic of the independent federal judiciary. ${ }^{129}$

Is a rule of jurisdiction over corporations as neutral as the rule under consideration in Byrd? A literal application of the outcome-determinative test stamps the choice of jurisdiction standards as having a substantial affect on the result of the suit, since in the only cases in which it makes any difference the defendant is subject to suit under one and not the other. ${ }^{130}$ Yet cause for reluctance to automatically apply state law is given by the obvious fact that such a choice says nothing of whether the plaintiff should be granted the requested relief. Just as the choice in Byrd is who should decide factual issues, the choice in Arrowsmith is where the issues should be decided. Both have a ring of neutrality. Thus there is a significant question whether the choice of jurisdiction standards affects the outcome; it may determine the outcome of this particular

$125 I d$. at 536 .

126 Id. at $536-37$.

127 Id. at 539 .

128 No statute or rule required the jury determination. The Court acknowledged the seventh amendment as evidence of a federal policy in favor of jury determinations, but expressly denied resting upon the possibility of a constitutional right to a jury trial. Id. at 537 n.10.

129 Id. at $537-38$.

130 See Abraham, supra note 106, at 528. 
attempt to sue in this particular court, but the resolution on the merits of the grievance between the parties is wholly unaffected.131

But even if there is a strong possibility that the choice will "affect the result of the litigation," whatever that means, Byrd indicates that the state law will not be applied in the face of a significant contrary federal policy. The policy of favoring jury decisions in factual disputes apparently reflects a judgment that the decisions reached in federal courts are more likely to be sound if a jury passes on the facts. What federal reason might there be for applying an independent judge-made rule of jurisdiction over corporations, presumably requiring less connection with the forum than that of the state, in a diversity action? The generally accepted basis for diversity jurisdiction is a federal interest in providing an alternate, unbiased forum for the nonresident party apprehensive of the treatment he might receive in the courts of the state in which he is litigating. ${ }^{132}$ This is no reason for requiring a corporate defendant to defend a diversity action in a federal court held in a state whose courts have no power over him. Apart from the inconvenience of the forum, it

131 In sustaining the validity of rule $4(f)$ the Supreme Court said, "Undoubtedly most alterations of the rules of practice and procedure may and often do affect the rights of litigants. . . The fact that the application of Rule $4(f)$ will operate to subject petitioner's rights to adjudication by the district court for northern Mississippi will undoubtedly affect those rights. But it does not operate to abridge, enlarge or modify the rules of decision by which that court will adjudicate its rights." Mississippi Pub. Corp. v. Murphree, 326 U.S. $438,445.46$ (1946).

It has been observed that in certain situations the application of a broader standard of personal jurisdiction by the federal courts might subject a defendant's rights to a body of substantive law to which they were not otherwise subject. In such a situation it might be inaccurate to say the resolution on the merits is wholly unaffected by the personal jurisdiction standard. See Kaplan, Amendments of the Federal Rules of Civil Procedure, 1961-1963 (pt. 1), 77 HaRv. L. REv. 601, 633-34 (1964).

132 See ALI Study of the Division of JuRisdiction Between STAte and Federal Courts 39 (Tent. Draft No. 1, April 30, 1963). Indeed, were we willing to concede that protection of the out-of-state defendant against provincial state bias is the only reason for entertaining diversity actions, the application of a broader federal standard of personal jurisdiction would be an unwarranted extension of diversity jurisdiction. Where there is no power over a defendant there can be no bias exerted against him. But if the role of diversity jurisdiction was ever so limited, it is not now. The new 100 mile "bulge" provision of FED. R. Crv. P. $4(f)$, providing jurisdiction over certain third parties who could not otherwise be joined, gives an indication of its more modern utility. Facilitating multi-party litigation which no one state can handle is a useful federal function. Discussion of the provision supports its use and validity in diversity actions. Kaplan, supra note 131, at 632; Vestal, supra note 101, at 1059-71. But see, Abraham, supra note 106, at 523, 535.

A recent comment has pointed out an equally appealing two-party litigation in which the federal courts could perform a similar function by employing a uniform federal standard not afflicted with customary state standard requirements that the action be brought by a resident or arise out of acts done within the state. Comment, Federal Jurisdiction over Foreign Corporations and the Erie Doctrine, 64 Colum. L. REv. 685, 706 (1964). 
might be unfair to subject him to the substantive or choice of law rules of that state when the state itself could not do so.133

Should the federal standard be applied because it presumably will encompass more potential defendants? This is not prima facie meritorious. The federal system performs a valid function, perhaps even a duty, in providing a forum for the resolution of controversies that no one state can resolve completely. ${ }^{134}$ The exercise of this function in multiparty litigation is evidenced by the recent amendment to rule $4(f)$ allowing service of process anywhere within 100 miles of the district court, regardless of state lines, to bring in certain third parties. Certainly this is salutary and could justify application of a broad federal standard in multi-party litigation, but this reason disappears in two-party litigation, e.g., Arrowsmith. ${ }^{135}$

A federal interest in the uniformity of the non-substantive rules applied in the federal courts might be advanced, ${ }^{136}$ but this point assumes the question whether the particular rule is one that requires uniformity. Moreover, the argument is betrayed by the fact that state law is incorporated by reference in several of the federal rules themselves, notably rules $4(\mathrm{~d})(7)$ and $4(\mathrm{e}) .^{137}$

It could be argued that a personal jurisdiction standard represents a significant policy of the federal judiciary-the manner in which it allocates judicial business. By analogy to Byrd, this argument would seem to be entitled to respect, but its factual foundation and the significance of the supposed policy are questionable. The broader the standard, the less it resembles a provision to channel litigation efficiently among the districts. Moreover, it must be recognized that the personal jurisdiction standard is not customarily viewed in this manner.

Perhaps an inquiry into motive will reveal the federal interest; it is clear why a plaintiff might urge the adoption of the more far-reaching federal standard, but why would a court buy the argument? The primary motivation of the "disinterested" advocates of a federal standard seems to be a strong conviction, similar to that articulated in Byrd, that this is an "essential characteristic" of the independent federal judiciary.138 For Judge Clark it was a symbol of the independence of the federal courts:

133 See Abraham, supra note 106, at 528; Kaplan, supra note 131, at 633-34.

134 See Abraham, supra note 106, at 521-22; Kaplan, supra note 131, at 632-34.

135 But see note 132 supra.

136 Cf. Degnan, The Law of Federal Evidence Reform, 76 HARv. L. REv. 275 (1962);

Ladd, Uniform Evidence Rules in the Federal Courts, 49 VA. L. REv. 692 (1963).

137 HLART \& WEChSLER 589.

138 Cf. Monarch Insurance Co. v. Spach, 281 F.2d 401, 407 (5th Cir. 1960): "A United States District Court clothed with power by Congress pursuant to the Constitution is not a mere adjunct to a state's judicial machinery." 
"Over-all is the issue of national subservience to the divisive policies of the [state] statute, a pattern of law at best belittling and undignified for the national courts ...."139 The independence of the federal courts is, like motherhood, a salutary cause, but it is also a rather general principle that must yield to a significant state interest that might be disserved by failure to apply the state standard in diversity actions.

Advocates of the application of a state standard attempt to draw support for their position from two Supreme Court cases barring suit by plaintiffs in diversity actions when suit on the same cause would have been barred by the state, Angel $v$. Bullington ${ }^{140}$ and Woods $v$. Interstate Realty Co.141 With regard to these cases it was said in Arrowsmith:

[I]t seems immaterial that in such cases the state policy is expressed as a closing of the door against a particular kind of suit or plaintiff rather than as a refusal to pull a particular kind of defendant through the door. ${ }^{142}$

In Angel a state policy against deficiency judgments would have been defeated if they could have been obtained in the district court; the rule was clearly bound up with state-created rights. In Woods the state's attempt to influence foreign corporations to "qualify" to do business by barring access to the courts if they did not would have been frustrated by allowing them to sue in the federal courts. But what state policy will be frustrated by allowing foreign corporations to be sued in the district courts even though they are not amenable to suit in the state court? The significant interest of the state would seem to be providing, insofar as it can, a local forum for residents who have been wronged by foreign corporations. It is not seen how the state would suffer if the federal court furthered that objective. ${ }^{143}$

It might be argued that restrictions on amenability to suit of foreign corporations-such as requirements that the suit be by a resident or arise out of incidents occurring within the state-represent a policy of avoiding the discouragement of business activity within the state by such corporations. ${ }^{144}$ If the premise-that corporations attach significant

139 Arrowsmith v. United Press Int'1, 320 F.2d 219, 240 (2d Cir. 1963).

140330 U.S. 183 (1947).

141337 U.S. 535 (1949).

142320 F.2d at 227.

143 See Note, 56 CoLUM. L. REv. 394, 399-400 (1956). Likewise, a state might decline to subject foreign corporations to suit on out-of-state claims to reduce the costs of administering courts or to lighten workloads, but it would in no way defeat this purpose if the federal courts allowed actions against those corporations on such claims. Note, 69 HARv. L. REv. 508, 524 (1956).

144 Jaftex Corp. v. Randolph Mills, Inc., 282 F.2d 508, 521-22 \& n.4 (2d Cir. 1960). 
weight to possible amenability to suit in determining whether to expand -were true, this might be a point well taken. Some evidence of its truth is the manner in which corporations conduct their activities outside their home states, e.g., recall the careful solicitation procedures described in International Shoe Co. $v$. Washington. ${ }^{145}$ Yet the argument that such restrictions evidence a definite state policy must be discounted by the observation that they quite possibly represent only attempts to preserve the constitutionality of the statute while providing the maximum possible use of the local forum to resident plaintiffs. ${ }^{146}$

As in the case of the federal interest inquiry, additional insight into the state policies may be gained by inquiring into the motives of the "disinterested" advocates of the application of state law. Frequent quotations of Mr. Justice Frankfurter's statement that in diversity cases the federal court is, "in effect, only another court of the State" reveal the sentiment that in order not to interfere with the state's administration of justice the federal system should bend in the direction of cooperation with the state; when in doubt, apply state law.147 Accordingly, the inclination is that even in the non-substantive area state law should always be applied unless a federal statute, rule or significant policy has displaced it.

This view has its counterpart in the previously mentioned notion of preserving the integrity of the independent federal judiciary. Both these are general "philosophies" of federalism, not specific policies linked directly to standards of personal jurisdiction over corporations. Indeed, there seem to be no such specific policies of any strength on either side.

The impression cannot be avoided that the choice of a standard of jurisdiction over corporations has innocently become the scene of a clash of these two philosophies. Weighed against each other they seem to cancel, but the view of the majority in Arrowsmith is clearly the more popular. All that can be offered for those disturbed by this situation is an analysis of how it came about and a suggested way to change it. The game was given away when the Federal Rules of Civil Procedure uprooted the standard of personal jurisdiction from its basis in the district organization of the federal courts, where it had been immune to the application of state law challenge. When the rules failed to provide what the standard of jurisdiction over corporations should be, that immunity was completely lost. And once the standard became embroiled in the application of state law controversy, the application of state standards be-

145326 U.S. 310 (1945).

146 Arrowsmith v. United Press Int'l, 320 F.2d 219, 241 (2d Cir. 1963).

147 Abraham, supra note 106, at 521-22. 
came inevitable because of the emerging presumption that state law should be applied unless displaced.

If, as is unlikely, ${ }^{148}$ sufficient dissatisfaction with this state of affairs should develop, it could be cured by amendment to rule $4 .{ }^{149}$ If this is done it should be accompanied by a thorough reevaluation of personal jurisdiction, venue and notice as they apply to corporations in the federal courts. ${ }^{150}$

148 See All, Study of the Division of Jurisdiction Between State and Federal Courts $\S \S 1301-03$ (Tent. Draft No. 1, April 30, 1963). The distinguished members of the Council submitting the study, which recommends restrictions on diversity of citizenship jurisdiction, proposed that the personal jurisdiction of the district court, be, in general, limited to that of the courts of the state in which it sits in diversity actions.

140 It could be questioned whether the framers of the Federal Rules of Civil Procedure intended to establish federal standards of personal jurisdiction independent of state law. In the materials recording the development of the original federal rules can be found an interesting exchange of correspondence between William D. Mitchell, Chairman of the Rules Advisory Committee, Dean, later Judge, Charles E. Clark, the Reporter, and a Mr. Lee O. Gregory, a member of the bar. Mr. Gregory, having seen a copy of the April 1936 Preliminary Draft of the rules, in which the provisions now in rule $4(d)(7)$ were located in rule $4(c)(6)$, suggested that the rules include a provision for service of non-residents similar to the Iowa statute which had been recently sustained by the Supreme Court in Henry L. Doherty Co. v. Goodman, 294 U.S. 623 (1935). The reply of Dean Clark to Mr. Gregory's suggestion seems somewhat inconsistent with the more recently expressed views of Judge Clark: "I note your present suggestion that we should go further and have a federal rule of the same effect where no rule exists in the states. This is a matter which our Committee should consider somewhat further, and I am wondering whether they will wish to go this far, inasmuch as they have generally taken the position of not wishing to go beyond state policy in matters of jurisdiction. This might well be claimed to be a substantial extension, no matter how desirable it is. ... When a state announces such a policy, it can well be taken over into the federal courts. Should this be done in the absence of a state policy to that effect?" 6 U.S. Supreme Court Advisory Comm. on Rules for Civil Procedure, Materials-Letter of Charles E. Clark to Lee O. Gregory dated June 22, 1936 (1938) (unpublished, unpaginated collection of materials). See also letter of Lee $\mathrm{O}$. Gregory to William D. Mitchell dated June 12, 1936, and Letter of William D. Mitchell to Charles E. Clark dated June 16,1936, included in the same volume of materials.

150 The plausible reform would seem to be one stripping service of process of all personal jurisdiction aspects, i.e., limiting its function solely to notification without regard to territorial limits, and replacing the muddled, three-pronged attempt to locate the proper place for trial which now inheres in concepts of venue, personal jurisdiction and service of process with a single, comprehensive statute or rule using convenience of the parties and witnesses, access to evidence, etc., as the factors in locating the trial. See Barrett, Venue and Service of Process in the Federal Courts-Suggestions fot Reform, 7 VAND. L. REv. 608, 628-29 (1954); cf. Note, 56 Colum. L. Rev. 394, 420 (1956). 